\title{
Word Pairs Total Score
}

National Cancer Institute

\section{Source}

National Cancer Institute. Word Pairs Total Score. NCI Thesaurus. Code C120338.

The total score from the Children's Memory Scale Word Pairs Immediate, Word Pairs Delayed, and Word Pairs Delayed Recognition. 